\title{
Reconstruction of the Catastrophic Outburst Floods of the Diexi Ancient Landslide-Dammed Lake in the Upper Minjiang River, Eastern Tibetan Plateau
}

Junxue Ma ( $\nabla$ jx_ma@cugb.edu.cn )

China University of Geosciences Beijing https://orcid.org/0000-0002-1922-2880

Jian Chen

China University of Geosciences Beijing

Zhijiu Cui

Peking University

Wendy Zhou

Colorado School of Mines

\section{Ruichen Chen}

China University of Geosciences Beijing

Chengbiao Wang

China University of Geosciences Beijing

\section{Research Article}

Keywords: Landslide dam, Ancient dammed lake, Landslide-dammed lake outburst floods (LLOFs), Peak discharge

Posted Date: April 12th, 2021

DOl: https://doi.org/10.21203/rs.3.rs-364424/v1

License: (c) (i) This work is licensed under a Creative Commons Attribution 4.0 International License.

Read Full License

Version of Record: A version of this preprint was published at Natural Hazards on February 6th, 2022. See the published version at https://doi.org/10.1007/s11069-022-05223-z. 


\title{
Reconstruction of the Catastrophic Outburst Floods of the Diexi Ancient Landslide-Dammed Lake in the Upper Minjiang River, Eastern Tibetan Plateau
}

Junxue Ma ${ }^{\mathrm{a}, \mathrm{b}}$, Jian Chen ${ }^{\mathrm{a}, \mathrm{b} *}$, Zhijiu Cui ${ }^{\mathrm{c}}$, Wendy Zhou ${ }^{\mathrm{b}}$, Ruichen Chen ${ }^{\mathrm{a}}$, Chengbiao Wang ${ }^{\mathrm{a}}$ ${ }^{a}$ School of Engineering and Technology, China University of Geosciences (Beijing), Beijing 100083, China

${ }^{b}$ Department of Geology and Geological Engineering, Colorado School of Mines, Golden, CO 80401, USA

${ }^{c}$ College of Urban and Environmental Sciences, Peking University, Beijing 100871, China

\begin{abstract}
Landslide-dammed lake outburst floods (LLOFs) may pose serious safety threats to nearby residents and their livelihoods, as well as cause major damages to the downstream areas in mountainous regions. This study presents the Diexi ancient landslide-dammed lake (DALL) in the Upper Minjiang River at the eastern margins of the Tibetan Plateau, which was known to an estimated previous maximal lake area of $1.1 \times 10^{7} \mathrm{~m}^{2}$ and an impounded volume of $2.9 \times$ $10^{9} \mathrm{~m}^{3}$. Then, at approximately $27 \mathrm{ka} \mathrm{BP}$, the ancient landslide dam failed and catastrophic LLOFs occurred. It was determined that the peak discharge of the Diexi ancient LLOFs could be reconstructed using regression, parametric, and boulder competence approaches. The reconstructed maximum peak discharge might be $72,232.66 \mathrm{~m}^{3} / \mathrm{s}$, with an average velocity of $17.23 \mathrm{~m} / \mathrm{s}$, indicating that the Diexi ancient LLOFs were the most gigantic outburst floods to
\end{abstract}

*Corresponding author. E-mail address: jianchen@,cugb.edu.cn (J. Chen). 
occur in the Upper Minjiang River Valley since the Late Pleistocene Period. The differences in the widths and slopes within the former and the later reaches of the dam indicated that the geomorphic influences on the river channel resulting from the DALL and its LLOFs have existed for tens of thousands of years. These findings were of major significance in deepening the understanding of the existence and disappearances of important river-knickpoints on a time scale of tens of thousands of years.

Keywords: Landslide dam; Ancient dammed lake; Landslide-dammed lake outburst floods (LLOFs); Peak discharge

\section{Introduction}

Natural processes, such as tectonic movements, climate changes, volcanic activities, biological forces, and chemical processes, can form different types of natural dams and dammed lakes. These include landslide-dammed lakes, glacier lakes, moraine-dammed lakes, volcanic lakes, and organic lakes (Ermini and Casagli, 1988; Evans, 1986; Clague and Evans, 2000; Dai et al., 2005; Korup and Montgomery, 2008; Pierce et al., 2010; Chen et al., 2013; van Gorp et al., 2013; Delaney and Evans, 2015; Emmer, 2017; Kataoka et al., 2018). In the category of natural dammed lakes, landslide-dammed lakes are widely found to exist in various parts of the world (Ermini, 2003; Korup, 2004; Dai et al., 2005; Dong et al., 2009; Butt et al., 2013; Zhou et al., 2013; Stefanelli et al., 2018; Chen et al., 2018; Fan et al., 2020). Landslide dams and dammed lakes are common geomorphic phenomena in the eastern and southern margins of the Tibetan Plateau in southwestern China (Dai et al., 2005; Korup and Montgomery, 2008; Cui et al., 2009; Chen et al., 2013; Wang et al., 2014a). Among the aforementioned landslides, many large-scaled ancient landslides had blocked rivers, forming ancient landslide-dammed 
lakes, as illustrated in Table 1.

The longevity of landslide-dammed lakes may vary from several minutes to millennia (Costa and Schuster, 1988; Korup, 2002; Ermini, 2003; Butt et al., 2013; Delaney and Evans, 2015; Chen et al., 2018). A stable dammed lake may exist for thousands of years and be utilized for hydroelectric generation or tourist attractions. However, unstable dams may fail and generate landslide-dammed lake outburst floods (LLOFs) causing destructive hazards. It is essential to assess the mechanism and processes related to the triggers and breaches of landslides and dammed lakes, and are of major significance in the reconstructions of previous events, as well as effective hazard mitigation.

China's Diexi ancient landslide-dammed lake (DALL) is a well-known case, and is located the Upper Minjiang River at the eastern margin of the Tibetan Plateau. This lake initially received widespread attention in the research studies which were conducted regarding the Diexi earthquake of 1933. A large number of in-depth examinations of the lacustrine sediment in the upstream area of the landslide dam were completed in the decades following the aforementioned earthquake event (Wang et al., 2011; Wang et al., 2014b; Wei et al., 2015). However, few research reports have presented data regarding the LLOFs and the outburst deposits in the downstream areas. In our previous field research studies, several outburst deposit bars were discovered to be distributed in the downstream areas of the relict ancient landslide dam, and were subsequently examined and analyzed (Ma et al., 2018; Chen et al., 2019). In this study, a summarization of the characteristics of the outburst floods of the DALL was presented, and the maximum peak discharge of the LLOFs was reconstructed based on geomorphic and sedimentary characteristics. Furthermore, this study discussed the failure 
mode of the DALL, along with the geomorphological effects of the DALL and its outburst flooding actions.

\section{Regional Geological Settings}

The Minjiang River is considered to be an important tributary of the Yangtze River, and originates from the southern Minshan Mountains in Songpan County. The Diexi Reach (31.5 to $32.5^{\circ} \mathrm{N}$; 103.5 to $104.5^{\circ} \mathrm{E}$ ) belongs to the middle section of the Upper Minjiang River. It is located between Songpan County and Maoxian County, at the eastern margin of the Tibetan Plateau (Fig. 1a). The river deeply incises the high mountains, where the valleys form deep Uor V-shaped gorges, with elevations of $1,500 \mathrm{~m}$ in the valleys and 3,000 $\mathrm{m}$ along the ridges. In addition, the river current is fast, with an average water surface gradient of approximately $10.3 \%$. Narrow valleys can be found in this region, with widths ranging between 100 and 200 m. Meanwhile, the broader rivers range between 200 and $350 \mathrm{~m}$ in width.

A well-known 'North-South Seismic Belt' of abrupt topographic changes is located in this area (Wang et al., 2011). Two groups of major active fault zones were observed to be developed in the study area, which are referred to as the Minjiang Fault Zone (F8, Fig. 1b) and the Huya Fault Zone (F9, Fig. 1b). The regional crustal stability in the study area has been determined to be largely controlled by the activities of Longmenshan-Minshan Fault Zone, which is characterized by frequent fault activities, frequent earthquakes, and poor stability. Several ancient dammed lakes (Wang et al., 2011), including the DALL, are located in the upper reaches of the Minjiang River, as detailed in Table 1.

The lithologies of the exposed bedrock in the area mainly include the Xinduqiao $\left(\mathrm{T}_{3} x\right)$, Jurassic $\left(\mathrm{T}_{3} z h\right)$, Zagu'nao $\left(\mathrm{T}_{2}\right)$, and Bocigou $\left(\mathrm{T}_{1} b\right)$ groups of the Triassic and Carboniferous- 
Permian Periods, and the Weiguan group $\left(\mathrm{Dwg}^{2}\right)$ of the Devonian Period. These include (fine) sandstone, phyllite, (sandy) limestone, and griotte, as shown in Fig. 1c. In addition, layers of the Quaternary Holocene-Pleistocene $\left(\mathrm{Q}_{1-4}\right)$ are widely distributed on the both sides of the river, including residual, alluvial, debris flow, and lacustrine deposits.

The climate in the study area has the characteristics of a subtropical plateau-continent monsoon climate. The average annual temperature is approximately $12^{\circ} \mathrm{C}$. It has been observed that more than $80 \%$ of the annual rainfall is concentrated within the period ranging from May to October, with an average annual rainfall of $420 \mathrm{~mm}$. The hydrographic system of the Minjiang River is a perennial river with an annual flow of 21.178 billion $\mathrm{m}^{3}$. Meanwhile, the average annual flow of the Diexi Reach area is approximately $700 \mathrm{~m}^{3} / \mathrm{s}$.

Based on the findings of previous studies of relict ancient landslide dams, it was noted that an abundance of lacustrine deposits existed in the upstream areas, and several well-preserved band-, fan-, or terrace-shaped outburst deposits could be observed the downstream areas of the Minjiang River (Fig. 1c) (Ma et al., 2018). This study selected a large relict ancient landslide dam located in the Diexi Valley, on the left bank of Minjiang River. The dam was approximately $3 \mathrm{~km}$ in length and $1 \mathrm{~km}$ in width, with the highest altitude observed to be $2,316 \mathrm{~m}$ (Figs. $2 \mathrm{~b}$ and 3). The lake sediment sections were preserved on the slope of the relict landslide dam and both sides of the Minjiang River within the upstream areas of the relict landslide dam, which measured approximately $30 \mathrm{~km}$ in length (Figs. 1c and 2). In addition, approximately $5 \mathrm{~km}$ of outburst deposits were found to be spread on both riverbanks at the downstream reach of the Diexi ancient landslide dam (Fig. 1c).

\section{Data Sources and Methods}




\subsection{Field Investigations and Dataset}

Detailed field investigations were conducted, including topographic reconnaissance and geomorphologic investigations, along with the determination of the extent and distribution of the deposits from the ancient lake, in order to clarify the formation and evolution of the gigantic DALL, as well as the ancient LLOFs induced by the dam failure. Several dozens of sections distributed over more than $50 \mathrm{~km}$ (from Zhenjiangguan to Shidaguan) were investigated along the Minjiang River and the Songping Valley, for purpose of obtaining sedimentary and geomorphologic evidence related to the DALL and its outburst floods. Then, the topographic reconnaissance and geomorphologic data, including the locations, altitudes, lengths, heights, and thicknesses of the profiles, were accurately measured in-situ.

The elevations and coordinates (longitude and latitude data) were measured using portable Trimble GeoExplorer 6000 Series global positioning system (GPS), with an accuracy of \pm 10 $\mathrm{cm}$. Meanwhile, the data related to the angles, distances, heights, and thicknesses were obtained using Newcon-OPTIK LRM 2200SI hand-held laser rangefinders (Distance: 10 to 2,200 m; accuracy: $\pm 1 \mathrm{~m}$ ), along with Nikon COOLSSHOT 40i devices (Distance: 7.5 to $590 \mathrm{~m}$; accuracy: $\pm 20 \mathrm{~cm}$ ). Along with the characteristics of the landslide dam, this study also required a high-quality digital elevation model (DEM) in order to accurately reconstruct the dam's previous reservoir. A 10 m DEM generated from the Advanced Shuttle Radar Topography Mission (ASTER) digital elevation model on August $6^{\text {th }}$ of 2013 , with a spatial reference of Krasovsky_1940_Albers was used in this study. The platform of ArcGIS v10.2 was used for the topographic data.

The powerful "spatial analysis" function of the ArcGIS can be used to calculate the water 
surface area and capacity of a reservoir, as well as the elevation of the water surface. In the present study, the extent of the previous barrier lake could be inferred from the distribution and sedimentary characteristics of the lacustrine deposits. According to field investigation results, the section of the lacustrine deposits near Zhenping Village, located approximately $30 \mathrm{~km}$ upstream from the Diexi landslide dam, were observed to be coarser, and fluvial sediment had emerged (Fig. 2c). These changes in the sedimentary facies inferred that this site may have been the end boundary of the DALL. The top of the sediment was determined to have an elevation of 2,355 $\mathrm{m}$ (Fig. 2c). These findings confirmed that the water surface elevation of the previous DALL was not lower than 2,355 $\mathrm{m}$. Therefore, it was assumed in this study that the original elevation of the previous lake surface was approximately $2,355 \mathrm{~m}$. Using this acquired information, a topographic map based on the 10 m DEM data was drawn in ArcGIS software Subsequently, the maximal water surface area and volume of the DALL before draining occurred were successfully reconstructed (Fig. 4).

\subsection{Approaches for the Peak Discharge Calculations}

To summarize the previous related study methods, three main types of methods were generally used to estimate the maximum peak discharge $\left(Q_{\mathrm{p}}\right)$ of dam-break events. Table 2 shows a summary of conventional methods and equations. The physical meanings and units of symbols lists are included in the Section Notation List.

\subsubsection{Regression Equations}

The models relied on a single or series of regression relationships derived from test case studies or observed historical dam failures, which were determined to be related to the observed peak discharge levels in order to accurately measure the impounded water volumes. These 
included the water heights or depths (Kirkpatrick, 1977; Cenderelli, 2000; Pierce et al., 2010); water storage levels or volumes (Evans, 1986; Walder and Costa, 1996; Walder and O'Connor, 1997); or combinations of the water height (depths) and storage (volumes) ( Macdonald and Langridgemonopolis, 1984; Costa, 1985; Costa and Schuster, 1988). It was found that such regression relationships were convenient for application purposes, but limited in their suitability. This was due to the fact that they generally neglected the inclusion of the basic hydraulic principles related to the breach initiation and enlargement processes (Westoby et al., 2014), and thereby only provided order-of-magnitude predictions of the probable peak discharge levels (Dai et al., 2005).

In the cases where reliable estimates of the time-to-peak flow were unavailable, providing that the geometric characteristics of the dam structure and its lake drainage basin were known, it was considered that the analysis of the empirical relationships could accurately provide an expeditious and simple approach to estimating the peak flows, and would be suitable for relatively basic hazard assessments (Morris et al., 2007). Therefore, in spite of the limitations of the regression equations, they may provide constructive guidance for the general evolution law of the LLOFs' peak discharge levels. In this study, the equations developed by Evans (1986), Costa and Schuster (1988), and Cenderelli (2000) were adopted for the reconstruction of the peak flow of Diexi ancient LLOFs, which were described as follows:

(i) Evans, 1986

$$
Q_{\mathrm{p}}=0.72\left(V_{\mathrm{w}}\right)^{0.53}
$$

(ii) Costa and Schuster, 1988

$$
Q_{\mathrm{p}}=0.0158 P E^{0.41}
$$


(iii) Cenderelli, 2000

$$
\begin{gathered}
Q_{\mathrm{p}}=24(d)^{1.73} \\
Q_{\mathrm{p}}=3.4(V)^{0.46} \\
Q_{\mathrm{p}}=1.9(V \cdot d)^{0.4}
\end{gathered}
$$

In this study, the results of the field research revealed that a number of lacustrine deposits directly covered the slope of the relict ancient landslide dam (D-I) located in Jiaochang Village. The thicknesses of these deposits were determined to be between 1 and $3 \mathrm{~m}$, and 2,302 $\mathrm{m}$ a.m.s.1. respectively (Figs. 2b and 3). It was supposed that the elevation of the lake surface after failure was 2,302 $\mathrm{m}$. The water surface elevations of Xiahaizi Lake and the previous DALL were 2,122 $\mathrm{m}$ a.s.1. and 2,355 $\mathrm{m}$ a.s.1., respectively (Fig. 2). Therefore, the previous dam height $\left(H_{\mathrm{d}}\right)$ and the drop in the lake level depth $(d)$ after breaching were determined to be 233 and $53 \mathrm{~m}$, respectively. Finally, the peak discharge $\left(Q_{\mathrm{p}}\right)$ of Diexi ancient LLOFs were successfully calculated using the aforementioned Eqs. (1) to (5).

\subsubsection{Parametric Equations}

It is noteworthy that the models had considered the semi-physical processes, although they were simplified. Generally, several parameters were taken into consideration, including the lake surface area and volume, lake geometric characteristics, water depth, breach geometric characteristics, flood routing time, and the erosion rate of breach development. The obtained data was applied in the simulations of the dam-break formation, lake drainage characteristics, and maximum peak discharge level (Fread, 1996; Morris et al., 2009; Capart, 2013). The models generally required detailed geometric data of the dam structure, as well as its material properties. The hydraulic conditions of the breach flood were also important in order to achieve 
accurate simulations. However, it has been found to be difficult to obtain all of the aforementioned parameters for ancient dammed lakes, since their failures were rarely recorded in historic literature. Among these previously used models, the physically based predictive equations developed by Walder and O'Connor (1997) were frequently adopted in the assessments of the peak discharge levels LLOFs. For example, Dai et al. (2005) estimated the peak flow $\left(Q_{\mathrm{p}}\right)$ of the LLOFs in southwestern China's Dadu River using Walder and O’Connor's predictive equations.

This study also adopted the approach developed by Walder and O'Connor (1997) to estimate the peak flow of the Diexi LLOFs as follows:

$$
\begin{gathered}
Q_{\mathrm{p}}=1.51\left(g^{0.5} d^{2.5}\right)^{0.06}(k V / d)^{0.94} \text { if } k V(g d)^{-0.5} d^{-3}<0.6 \\
Q_{\mathrm{p}}=1.94 g^{0.5} d^{2.5}\left(D_{\mathrm{c}} / d\right)^{0.75} \text { if } k V(g d)^{-0.5} d^{-3} \gg 1
\end{gathered}
$$

Where the erosion rate $(k)$ at the breach was determined by the following:

$$
k=d / t
$$

\subsubsection{Boulder Competence Methods}

In previous research approaches, in accordance with the dynamic characteristics of outburst floods, the relationships between the energy parameters of the flow and the geometric characteristics of the sediment particles being transported by the floods were established in order to estimate the peak flow levels of the outburst floods (Costa, 1983; O'Connor, 1993). An assumption is generally taken into account in the aforementioned relationships that the largest boulders presented in the flood deposits can generally represent the maximum transporting energy of the outburst floods. Bradley and Mears (1980) were some of the earliest practitioners of these approaches. They estimated the average velocities and depths of paleo flooding events 
along Boulder Creek in Boulder, Colorado (US) using large boulders excavated from the flood plains. In addition, Costa (1983) extended and modified their work, and comprehensively summarized the utilized approaches.

The boulder competence methods can generally divided into three steps as follows: Computations of the average values of the velocity, average depth, and peak discharge levels. In this study, two theoretical relationships and one method were used to reconstruct the average velocity and average depth of the Diexi ancient LLOFs, respectively.

\section{Step One: Reconstruction of the Average Velocity $(\bar{v})$}

The two theoretical methods used to compute the average velocity were the Helley Method (balancing forces using turning moments) (Helley, 1969) and the Bradley-Mears Method $\left(F_{\mathrm{D}}+F_{\mathrm{L}}=F_{\mathrm{R}}\right)($ Bradley and Mears, 1980). The Helley Method was adopted to calculate the "bed-velocity" $\left(v_{\mathrm{b}}\right)$, which represented a fluid velocity of approximately $1 / 3$ grain diameter above the mean bed level obtained by equating the turning moments for fluid, drag, and lift with the resisting moments of the submerged particle weights (Costa, 1983). The method was simplified by Helley (1969) as follows:

$$
v_{\mathrm{b}}=3.276 x\left[\frac{\left(\gamma_{\mathrm{s}}-1\right) d_{\mathrm{L}}\left(d_{\mathrm{I}}+d_{\mathrm{S}}\right)^{2} M R_{\mathrm{L}}}{C_{\mathrm{D}} d_{\mathrm{S}} d_{\mathrm{L}} M R_{\mathrm{D}}+C_{\mathrm{L}} d_{\mathrm{I}} d_{\mathrm{L}} M R_{\mathrm{L}}}\right]^{0.5}
$$

Then, the average flood velocity is estimated using the following equation:

$$
\bar{v}=1.2 v_{\mathrm{b}}
$$

According to Bradley and Mears (1980), at incipient motion, the fluid drag $\left(F_{\mathrm{D}}\right)$ and the fluid lift forces $\left(F_{\mathrm{L}}\right)$ are equal the gravitational and frictional forces $\left(F_{\mathrm{R}}\right)$ acting on a boulder, and can be written as follows:

$$
F_{\mathrm{D}}+F_{\mathrm{L}}=F_{\mathrm{R}}
$$


The fluid drag $\left(F_{\mathrm{D}}\right)$ and the fluid lift forces $\left(F_{\mathrm{L}}\right)$, along with the gravitational and frictional forces $\left(F_{\mathrm{R}}\right)$, were determined in this study using the following equations:

$$
\begin{gathered}
F_{\mathrm{D}}=C_{\mathrm{D}} A_{\mathrm{n}}\left(\gamma_{\mathrm{f}} v_{\mathrm{b}}{ }^{2}\right) / 2 \\
F_{\mathrm{L}}=C_{\mathrm{L}} A_{\mathrm{p}}\left(\gamma_{\mathrm{f}} v_{\mathrm{b}}{ }^{2}\right) / 2 \\
F_{\mathrm{R}}=\left(\gamma_{\mathrm{s}}+\gamma_{\mathrm{f}}\right) V_{\mathrm{p}} g(f \cos \varphi-\sin \varphi)
\end{gathered}
$$

The equations were then simplified for solving the $v_{\mathrm{b}}$ as follows:

$$
v_{\mathrm{b}}=\left[\frac{2\left(\gamma_{\mathrm{s}}-1\right) d_{\mathrm{I}} g f}{\gamma_{\mathrm{f}}\left(C_{\mathrm{L}}+C_{\mathrm{D}}\right)}\right]^{0.5}
$$

Similarly, the bottom velocity was also multiplied by 1.2 in order to obtain the estimated average flood velocity $(\bar{v})$.

\section{Step Two: Estimation of the Average Depth $(\bar{D})$}

The formula which was used in this study to estimate the average depth was the Manning Formula (Williams, 1970). The Manning Formula reconstructed the depths of the floods from the particle-size data as follows:

$$
\bar{D}=\left(\frac{\bar{v} n}{\sqrt{S}}\right)^{1.5}
$$

\section{Step Three: Peak Discharge Calculations $\left(Q_{\mathrm{p}}\right)$}

The maximum flood peek discharge level was calculated in this study using the following equation:

$$
Q_{\mathrm{p}}=\bar{v} A
$$

At that point in this study's investigations, the only remaining unknown was the flow surface width, which could be obtained from the cross-sections located in the flood valley near the boulder deposits sites. The shapes of the calculated cross-sections had major influences on the peak discharge levels. In the current study, for convenience purposes, it was approximately 
assumed that the calculating cross sections were trapezoidal. Subsequently, the section areas could be calculated using the average depths, slopes of both banks of the valley, and the widths of the riverbed at the cross-section sites. It should be pointed out that due to these approximation treatments of the calculated cross-sections, there was a possibility that the maximum peak discharge levels may have produced some errors. Fortunately, for ultra-largescaled outburst floods, such error effects are considered to be acceptable.

In this study, five cross-sections were established to calculate the peek discharge levels of the Diexi ancient LLOFs, as detailed in Fig. 5. In addition, the intermediate and long axis of the largest bounders of the outburst deposits near the cross-sections were measured (Table 3 ). The detailed river parameters and the estimated peek discharge levels are also listed in Table 3.

\section{Results}

\subsection{Characteristics of the Outburst Deposits Induced by the Diexi Ancient}

\section{LLOFs}

Several field investigations were conducted in the Diexi Region, and a total eight outburst deposit sections were discovered in the downstream reach areas of the dam. The lithologic characteristics of the exposed profiles of the outburst deposits sections are detailed in Fig. 6 . In the figure, Sections II, III, and V to VII were obtained from the reports presented by Ma et al. (2018). In our previous research, the three Optically-Stimulated Luminescence (OSL) dating samples ages of $20.9 \pm 3.1,27.3 \pm 2.8$, and $22.7 \pm 3.4$ ka BP were tested, respectively (Fig. 6). The results revealed that the failure time of the DALL was approximately $27 \mathrm{ka} \mathrm{BP}$, or during the Late Pleistocene Period, as previously explained by Ma et al. (2018). The distribution and geomorphological characteristics of the outburst deposits are detailed in Table 5, in which the 
calculating parameters for the reconstruction of the outburst floods are provided. In addition, the accuracy of the calculation results was verified using the obtained data.

It was found in this study that the outburst deposits possessed a distinctive sedimentary sequence, and presented a transition pattern of unordered to sub-ordered or ordered from the upstream to the middle and lower reaches (Fig. 7). It was found that near the breaching gate, the diamict profiles displayed mixed and disordered sedimentary characteristics, with no distinct bedding and structural characteristics. It was observed that the gravel was mainly angular and poorly arranged in the profile, possessing mixed sizes and containing some isolated boulders (Fig. 7b). Also, at approximately $0.3 \mathrm{~km}$ downstream, some sedimentary layers appeared in the profile of the outburst deposits, and clustered boulders formed coarse gravel layers which presented a certain sequence (Fig. 7c). Then, in the middle and lower reaches, the sedimentary layers and bedding became increasingly obvious. These coarser gravel layers and fine sand and gravel layers composed rhythmic units represented the various "cycles" in the lower segments (Fig. 7d). There were also gravel diara deposits formed by well-rounded and well-sorted pebble gravel found in the river near the end of outburst deposits, which were found to present imbrication structures (Fig. 7e). These special sedimentary features explained the hydrodynamic changes which had occurred during the propagation of the outburst floods, and were also important indicators for distinguishing the outburst deposits from the other types of sediment in the study area.

\subsection{Peak Discharge Levels of the Diexi LLOFs}

This study estimated that the original maximal water surface area of the Diexi ancient lake was $1.1 \times 10^{7} \mathrm{~m}^{2}$, with a corresponding volume of $2.9 \times 10^{9} \mathrm{~m}^{3}$, as shown in Fig. 4. Subsequently, 
the peak discharge $\left(Q_{\mathrm{p}}\right)$ of the Diexi ancient LLOFs was estimated at $74,542 \mathrm{~m}^{3} / \mathrm{s}$ using Eq. (1); 48,446 m³ $/ \mathrm{s}$ using Eq. (2); 23,079 m³ $/ \mathrm{s}$ using Eq. (3); 76,592 $\mathrm{m}^{3} / \mathrm{s}$ using Eq. (4); and 56,679 $\mathrm{m}^{3} / \mathrm{s}$ using Eq. (5).

It was also inferred in this study that the failure incentive of the Diexi ancient landslide dam was triggered by the overtopping actions following the overflow water erosion induced by earthquake-related rock falls or sub-landslides, as detailed in Section 5.1. It was indicated that the formation time for the breach was very short. Therefore, Eq. (7) was applied in this study. The height $\left(D_{\mathrm{c}}\right)$ of the dam crest relative to the dam base had taken the same value as the drop in lake level depth $(d)$, or $53 \mathrm{~m}$. Accordingly, the peak discharge rate at the dam breach was estimated to be $12,4195 \mathrm{~m}^{3} / \mathrm{s}$.

In regard to the boulder competence methods, the calculated results of the average velocities and average depths obtained using Eqs. (9) to (16) are listed in Table 3. The peak flow rates at the five cross-sections were calculated using Eq. (17), as shown in Table 3. It was revealed that the maximum average velocity and peak discharge of the Diexi LLOFs were $17.23 \mathrm{~m} / \mathrm{s}$ and $72,232.66 \mathrm{~m}^{3} / \mathrm{s}$, respectively.

It was clear from the obtained results that the peak discharge levels of the Diexi ancient LLOFs were very variable when using the three different types of approaches, with a range of 23,079 to $124,195 \mathrm{~m}^{3} / \mathrm{s}$. The values obtained from Eqs. (1), (4), and (17) were approximate values. However, the estimated peak discharges of 124,195 m³/s by Eq (7) was too larger than that by other equations. As can be seen Fig. 3, it was estimated that the cross-sectional area measured approximately $36,040 \mathrm{~m}^{2}$ with a flow depth of $53 \mathrm{~m}$. Therefore, based on the results obtained using Eqs. (1) to (5) and Eq. (7), the mean flow velocities were 2.07, 1.34, 0.64, 2.13, 
1.57 , and $3.45 \mathrm{~m} / \mathrm{s}$, respectively, which seemed to be unreasonably smaller than the value of $17.23 \mathrm{~m} / \mathrm{s}$ which had been implied in the boulder competence method results (Fig. 8). In addition, the water surface elevation of the LLOFs calculated by the Manning Formula (Eq. (16) was consistent with the top elevation of the outburst deposits shown in Fig. 9. Therefore, this study considered that the boulder competence methods may have been more reasonable than the other approaches. Subsequently, it was considered to be acceptable that the estimated maximum average velocity and the peak discharge level of the Diexi ancient LLOFs were 17.23 $\mathrm{m} / \mathrm{s}$ and $72,232.66 \mathrm{~m}^{3} / \mathrm{s}$, respectively.

According to the "Qiang People's Autonomous County Annals of Maowen" (Local Chronicle Compilation Committee of the Qiang People's Autonomous County of Maowen and the Tibetan and Qiang People's Autonomous Prefecture of Aba, Sichuan Province, 1997), the average annual flow of the Minjiang River is approximately $700 \mathrm{~m}^{3} / \mathrm{s}$. In this study, the estimated maximum peak discharge of the Diexi ancient LLOFs was estimated to be more than one hundred times the average annual flow of the Minjiang River, indicating that they were the largest outburst flooding events in the Upper Minjiang River Valley since the Late Pleistoncene Period.

\section{Discussion}

\subsection{Failure Mode of the Diexi Ancient Landslide Dam}

It is generally known that landslide dams commonly fail by overtopping and erosion actions caused by externally triggered overflow channels. These external triggers include snow-ice avalanches or calving, rock falls, and sub-landslides, which become intensified by the lack of channelized spillways or other protected outlets (Costa and Schuster, 1988; Clague and Evans, 
2000; Ermini and Casagl, 2003). Costa and Schuster (1988) summarized that in the majority of the cases examined in previous studies, the dam-breaches were triggered by the fluvial erosion of landslide material. In addition, the head-cutting had progressively moved upstream toward the lake. More than $90 \%$ of the landslide dams examined in their study had failed under those conditions. Peng and Zhang (2012) documented that 91\% (131 cases out of the 144 cases with known failure modes) of the dams failed through overtopping actions. Additional known modes include piping and slope failures. The seepage through the dams potentially led to internal erosion and piping failures if the dam materials were loose and non-compacted, forming seepage channels on the downstream faces of the dams (Costa and Schuster, 1988). The mode of slope failure was observed to be rare since the majority of the natural landslide dams tended to have high width-to-height ratios, and slope faces of the upstream and downstream areas tended to gentle. In this study, it was estimated that the Diexi ancient landslide dam had a high width-to-height ratio (more than $10 \mathrm{~m} / \mathrm{m}$ ) which had formed a relatively stable structure. In addition, no leakage traces were found on the downstream side of the relict dam. Therefore, it was deduced that the dam breach in the Diexi Region was not triggered by piping or slope failure. Consequently, it was inferred that overtopping actions, followed by erosion by overflow water induced by earthquake-related rock avalanches, were the failure incentives of the Diexi ancient landslide dam.

\subsection{Geomorphological Effects of the DALL and LLOFs}

Landslide dams which have existed for long periods of time can potentially generate significant influences on the evolution of river systems by controlling the patterns and rates of intermontane sedimentation, as well as the migration of sediment. As a result, valley landforms 
may be modified, such as the creation of local base levels, retreats in the river knickpoints, and the reorganization of river networks (Korup, 2005; Korup et al., 2010; Hood et al., 2014;Yunus et al., 2016; Fan et al., 2020). Moreover, the impacts on fluvial landforms generally persisted for quite some time, potentially even thousands to tens of thousands of years (Burchsted et al., 2014; Burchsted and Daniels, 2014). Korup and Tweed (2007) suggested that even alpine belts with high erosion rates may retain geomorphic and sedimentary evidence of dam-breaking events. One of the most direct consequences of the landslide dams was the imposition of variations in the river incision rates (Costa and Schuster, 1988; Korup, 2005; Ouimet et al., 2007). Furthermore, the migration of sediment is known to have been significantly controlled by large-scaled landslide dams and their drainage processes (Pratt-Sitaula et al., 2007; Korup, 2012).

It was found in previous studies that lacustrine sediment could be commonly observed in the upstream areas of long-term landslide dams in high mountain regions (Montgomery et al., 2004). Furthermore, in the downstream regions of landslide dams, evidence of outburst sediment may also be well preserved for thousands of years (Cutler et al., 2002; Carling, 2013; Chen et al. 2018). In the Diexi Region, it was observed that thick lacustrine sediment had extended in the upper reach of the Diexi landslide dam of the Minjiang River for tens of thousands years, with a length of approximately $30 \mathrm{~km}$ and a maximum thickness of more than $200 \mathrm{~m}$ (Wang et al., 2014b; Ma et al., 2018; Xu et al., 2020). In addition, it has been found that below the dam, the high-energy outburst floods delivered coarse diamict boulders from the landslide dam to the downstream areas. These types of diamict sediment usually formed bandor terrace-shaped outburst deposit bars, among which the largest one had an maximum exposed 
profile length of approximately $200 \mathrm{~m}$, and ranged up to $25 \mathrm{~m}$ in height (Ma et al., 2018). The long-term accumulation of these types of sediment had significant impacts on the evolution of the Minjiang River.

Fig. 10 details the average slope values within the $30 \mathrm{~km}$ upstream area and the $8 \mathrm{~km}$ downstream area of the landslide dam, which were $1.63 \%$ and $3.88 \%$, respectively. These findings indicated that the average slope in the downstream was more than twice of the upstream. Furthermore, the average channel width in the lower reach of the dam was determined to be $263 \mathrm{~m}$, which was smaller than that in the upper reach in which the average value was $300 \mathrm{~m}$. Therefore, it was clear that the geomorphic influences on the river channel from the DALL and its LLOFs had existed for tens of thousands of years. The lacustrine sediment above the landslide dam had promoted the channel deposition, as well as impeding the erosion action. However, the LLOFs encouraged erosion of the riverbed and riverbanks. A number of other similar studies have also been conducted in southwestern China in the southeastern section of the Tibetan Plateau (Ouimet et al., 2007; Chen et al., 2013; Wang et al., 2014a; Liu et al., 2018; Chen et al., 2018). It is suggested that well-informed future research studies should be carried out for systematically understanding the implications of ancient landslide-dammed lakes and their potential for flooding.

\section{Conclusions}

This study selected the Diexi ancient landslide-dammed lake as the study object. This dammed lake is believed to have existed for a long period of time, forming thick lacustrine sediment in the upstream areas of the Upper Minjiang River at the eastern margin of the Tibetan Plateau. It was estimated that the previous maximal lake area was $1.1 \times 10^{7} \mathrm{~m}^{2}$, with a lake surface 
elevation of 2,355 m, and an impounded volume was $2.9 \times 10^{9} \mathrm{~m}^{3}$. It is believed that at approximately $27 \mathrm{ka}$ BP, during the late Pleistocene Period, the ancient landslide dam failed due to the overtopping actions. The subsequent LLOFs formed large amounts of outburst deposits in the downstream areas of the landslide dam, with an estimated length of approximately $5 \mathrm{~km}$ along the Minjiang River. These outburst deposits possessed a distinctive sedimentary sequence which was completely lacking in other sedimentary types. It was observed that a change pattern of unordered to sub-ordered or ordered existed from the upstream to the middle and lower reaches, which indicated the changes in energy and medium during the transport and accumulation processes.

Furthermore, this study systematically summarized the empirical methods for estimating peak discharge levels of outburst floods. It was found that the different approaches, including regression equations, parametric equations, and boulder competence methods, tended to produce disparate values, at least in regard to the order of magnitude. However, this study considered that it was reasonable to accept that the maximum average velocity and peak discharge of the Diexi ancient LLOFs were $17.23 \mathrm{~m} / \mathrm{s}$ and $72232.66 \mathrm{~m}^{3} / \mathrm{s}$, respectively. It was also noted that there was a possibility of over- or under-estimating the values of the peak flow due to the extra uncertain or approximated parameters. It was found that the best practice for reconstructing the peak discharge of the ancient LLOFs seemed to be collecting the accurate flood water levels in the downstream areas, and then re-calculating the peak discharge under unsteady flow conditions (Fread, 1996; Dai et al., 2005; Liu et al., 2019).

Large ancient landslide-dammed lakes and their LLOFs can have significant impacts on river evolution. The differences in the widths and slopes within the former and behind the reaches 
of the dam indicated that the geomorphic influences on the river channel from the DALL and its LLOFs had existed for tens of thousands of years. Therefore, it is of major significance to deepen the current understanding of the existence and disappearance of important riverknickpoints on a time scale of tens of thousands of years.

\section{Acknowledgments}

This research study was supported by the National Natural Science Foundation of China (Grant nos. 41571012 and 41230743), and the State Scholarship Fund (Grant nos. 201906400025 and 201906405034) from the China Scholarship Council (CSC). The authors would like to express their sincere appreciation to the Editor of the journal, along with the anonymous reviewers, for their critical reviews and efforts which were devoted to improving this manuscript, and also for their helpful comments and suggestions.

\section{Notation List}

The following symbols are used in this paper:

$Q_{\mathrm{p}}=$ the peak flood discharge $\left(\mathrm{m}^{3} / \mathrm{s}\right) ;$

$H_{\mathrm{d}}=$ height of dam (m);

$d=$ lake level drop $(\mathrm{m})$;

$V$ or $V_{\mathrm{w}}=$ volume of the water behind the dam at failure $\left(\mathrm{m}^{3}\right)$;

$H_{\mathrm{w}}=$ depth of water above breach invert at time of failure (m);

$S_{\mathrm{w}}=$ reservoir storage at normal pool $\left(\mathrm{m}^{3}\right)$;

$P E=$ the product of dam height $(\mathrm{m})$, lake volume $\left(\mathrm{m}^{3}\right)$ and the specific weight of water $\left(9,800 \mathrm{~N} / \mathrm{m}^{3}\right)$

$W_{\mathrm{t}}=$ top breach width $(\mathrm{m})$;

$g=$ gravitational acceleration $\left(9.8 \mathrm{~m} / \mathrm{s}^{2}\right)$; 
$W_{\mathrm{b}}=$ basal breach width (m);

$H_{\mathrm{b}}=$ effective head through breach;

$C_{\mathrm{d}}=$ weir flow coefficient;

$z=$ sidewall slope of breach sides;

$t_{\mathrm{w}}=\mathrm{a}$ time constant with an approximate range between 1,000 and 2,000 s;

$k=$ the erosion rate at the breach $(\mathrm{m} / \mathrm{s})=d / t$, where $t$ is the time for the breach to form $(\mathrm{s})$;

$D_{\mathrm{c}}=$ the height of the dam crest relative to the dam base (m);

$A=$ is the trapezoidal cross-sectional channel area $\left(\mathrm{m}^{2}\right)$;

$v=$ the average flow velocity $(\mathrm{m} / \mathrm{s})$;

$C_{\mathrm{D}}=$ drag coefficient (from Fig. 3 in Helley, 1969, p. G4);

$C_{\mathrm{D}^{\prime}}=$ adjusted drag coefficient, $C_{\mathrm{D}^{\prime}}=0.75 C_{\mathrm{D}}$ (from Fig. 3 in Helley, 1969, p. G4);

$C_{\mathrm{L}}=$ lift coefficient;

$d \mathrm{~s}=$ short axis $(\mathrm{m})$

$d_{\mathrm{I}}=$ intermediate axis $(\mathrm{m})$;

$d_{\mathrm{L}}=$ long axis $(\mathrm{m})$

$\gamma_{\mathrm{s}}=$ specific weight of particle $\left(28,500 \mathrm{~N} / \mathrm{m}^{3}\right)\left(2.8 \mathrm{~g} / \mathrm{cm}^{3}\right)$;

$\gamma_{\mathrm{f}}=$ specific weight of fluids $\left(10,000 \mathrm{~N} / \mathrm{m}^{3}\right)\left(1.0 \mathrm{~g} / \mathrm{cm}^{3}\right)$;

$M R_{\mathrm{L}}=$ lift turning moment $=\left(d_{\mathrm{l}} / 4\right) \cos \theta+\left(\sqrt{3 / 16 d_{\mathrm{S}}{ }^{2}}\right) \sin \theta($ from Helley, 1969, p. G4);

$M R_{\mathrm{D}}=\mathrm{drag}$ turning moment $=0.1 d \mathrm{~s} \cos \theta+\left(\sqrt{3 / 16 \mathrm{~d}_{S}^{2}}\right) \cos \theta$ (from Helley, 1969, p. G4);

$\theta=$ imbrication angle (degrees);

$n=$ Manning roughness coefficient (Barnes, 1967);

$S=$ channel slope $(\mathrm{m} / \mathrm{m}) ;$ and 
$f=$ Darcy-Weisbach friction factor.

\section{References}

Costa JE, Schuster RL (1988) The Formation and Failure of Natural Dams. Geological Society of America Bulletin 100(7):1054-1068.

Evans SG (1986) The maximum discharge of outburst floods caused by the breaching of manmade and natural dams. Canadian Geotechnical Journal 23(3):385-387.

Clague JJ, Evans SG (2000) A review of catastrophic drainage of moraine-dammed lakes in British Columbia. Quaternary Science Reviews 19(17-18):1763-1783.

Dai FC, Lee CF, Deng JH, Tham LG (2005) The 1786 earthquake-triggered landslide dam and subsequent dam-break flood on the Dadu River, southwestern China. Geomorphology 65(34):205-221.

Korup O, Montgomery DR (2008) Tibetan plateau river incision inhibited by glacial stabilization of the Tsangpo gorge. Nature 455(7214):786-789.

Pierce MW, Thornton CI, Abt SR (2010) Predicting Peak Outflow from Breached Embankment Dams. Journal of Hydrologic Engineering 15(5):338-349.

Chen J, Dai FC, Lv TY, Cui ZJ (2013) Holocene landslide-dammed lake deposits in the Upper Jinsha River, SE Tibetan Plateau and their ages. Quaternary International 298:107-113.

van Gorp W, Veldkamp A, Temme A, Maddy D, Demir T, van der Schriek T, Reimann T, Wallinga J, Wijbrans J, M.Schoorl J (2013) Fluvial response to Holocene volcanic damming and breaching in the Gediz and Geren rivers, western Turkey. Geomorphology 201:430448.

Delaney KB. Evans SG (2015) The 2000 Yigong landslide (Tibetan Plateau), rockslide- 
dammed lake and outburst flood: Review, remote sensing analysis, and process modelling. Geomorphology 246:377-393.

Emmer A (2017) Geomorphologically effective floods from moraine-dammed lakes in the Cordillera Blanca, Peru. Quaternary Science Reviews 177:220-234.

Kataoka KS, Matsumoto T, Saito T, Kawashima K, Nagahashi Y, Iyobe T, Sasaki A, Suzuki K (2018) Lahar characteristics as a function of triggering mechanism at a seasonally snowclad volcano: contrasting lahars following the 2014 phreatic eruption of Ontake Volcano, Japan. Earth, Planets and Space 70:113, 28 pp.

Chen J, Zhou W, Cui ZJ, LiWC, Wu SE, Ma JX (2018) Formation process of a large paleolandslide-dammed lake at Xuelongnang in the upper Jinsha River, SE Tibetan Plateau: constraints from OSL and ${ }^{14} \mathrm{C}$ dating. Landslides 15(12):2399-2412.

Korup O (2004) Geomorphometric characteristics of New Zealand landslide dams. Engineering Geology 73(1-2):13-35.

Dong JJ, Tung YH, Chen CC, Liao JJ, Pan YW (2009) Discriminant analysis of the geomorphic characteristics and stability of landslide dams. Geomorphology 110(3-4):162-171.

Dong JJ, Tung YH, Chen CC, Liao JJ, Pan YW (2011) Logistic regression model for predicting the failure probability of a landslide dam. Engineering Geology 117(1-2):52-61.

Butt MJ, Umar M, Qamar R (2013) Landslide dam and subsequent dam-break flood estimation using HEC-RAS model in Northern Pakistan. Natural Hazards 65(1):241-254.

Zhou JW, Cui P, Fang H (2013) Dynamic process analysis for the formation of Yangjiagou landslide-dammed lake triggered by the Wenchuan earthquake, China. Landslides 10(3):331-342. 
Stefanelli CT, Vilimek V, Emmer A, Catani F (2018) Morphological analysis and features of the landslide dams in the Cordillera Blanca, Peru. Landslides 15(3)507-521.

Peng M, Zhang LM (2012) Breaching parameters of landslide dams. Landslides 9(1):13-31.

Zhang YS, Zhao XT, Lan HX, Xiong TY (2011) A Pleistocene landslide-dammed lake, Jinsha River, Yunnan, China. Quaternary International 233(1):72-80.

Wang LS, Wang XQ, Xu XN, Cui J (2007) What happened on the upstream of Minjiang River in Sichuan Province 20,000 years ago? Earth Science Frontiers 14(4):189-196. (in Chinese with English abstracts)

Wu LZ, Deng H, Huang RQ, Zhang LM, Guo XG, Zhou Y (2018) Evolution of lakes created by landslide dams and the role of dam erosion: A case study of the Jiajun landslide on the Dadu River, China. Quaternary International 503(Part A):41-50.

Fan XM, Dufresne A, Subramanian SS, Strom A, Hermanns R, Stefanelli CT, Hewitt K, Yunus AP, Dunning S, Capra L, Geertsema M, Miller B, Casagli N, Jansen JD, Xu Q (2020) The formation and impact of landslide dams - State of the art. Earth-Science Reviews 203:103116, 28 pp.

Korup O (2002) Recent research on landslide dams - a literature review with special attention to New Zealand. Progress in Physical Geography 26(2):206-235.

Raj KBG, Martha TR, Kumar KV (2017) A bird's-eye view of landslide dammed lakes in Zanskar Himalaya, India. Current Science 112(6):1109-1112.

Cui P, Zhu YY, Han YS, Chen XQ, Zhuang JQ (2009) The 12 May Wenchuan earthquakeinduced landslide lakes: distribution and preliminary risk evaluation. Landslides 6(3):209223. 
Wang PF, Chen J, Dai FC, Long W, Xu C, J Sun M, Cui ZJ (2014a) Chronology of relict lake deposits around the Suwalong paleolandslide in the upper Jinsha River, SE Tibetan Plateau: Implications to Holocene tectonic perturbations. Geomorphology 217:193-203.

O’Connor JE, Clague JJ, Walder JS, Manville V, Beebee RA (2013) 9.25 Outburst Floods. In Treatise on Geomorpholog, edited by Shroder FS, 475-510. Academic Press, San Diego (United States).

Liu WM, Carling PA, Hu KH, Wang H, Zhou Z, Zhou LQ, Liu DZ, Lai ZP, Zhang XB (2019) Outburst floods in China: A review.” Earth-Science Reviews 197:102895, 14 pp.

Ma JX, Chen J, Cui ZJ, Zhou W, Liu C, Guo P, Shi Q (2018) Sedimentary evidence of outburst deposits induced by the Diexi paleolandslide-dammed lake of the upper Minjiang River in China. Quaternary International 464(Part B):460-481.

Wang P, Zhang B, Qiu WL, Wang JC (2011) Soft-sediment deformation structures from the Diexi paleo-dammed lakes in the upper reaches of the Minjiang River, east Tibet. Journal of Asian Earth Sciences 40(4):865-872.

Wang XQ, Li YR, Yuan Y, Zhou Z, Wang LS (2014b) Palaeoclimate and palaeoseismic events discovered in Diexi barrier lake on the Minjiang River, China. Natural Hazards and Earth System Sciences 14(8):2069-2078.

Wei YF, Wang XQ, Sheng M, Zhou Z, Yuan Y (2015) Reproduction of the sedimentary disturbance phenomenon of the Diexi ancient landslide-dammed lake under earthquake. Journal of Mountain Science 12(5):1181-1188.

Kirkpatrick GW (1977) Evaluation guidelines for spillway adequacy. In Proc., Evaluation of Dam Safety; Engineering Foundation Conference 395-414. Pacific Grove, California: 
American Society of Civil Engineers.

Cenderelli DA (2000) Floods from natural and artificial dam failures.” In Inland Flood Hazards: human, riparian and aquatic communities, edited by Wohl EE, 73-103. Cambridge University Press, New York (United States).

Pierce MW, Thornton CI, Abt SR (2010) Predicting Peak Outflow from Breached Embankment Dams. Journal of Hydrologic Engineering 15(5):338-349.

Walder JS, Costa JE (1996) Outburst floods from glacier-dammed lakes: The effect of mode of lake drainage on flood magnitude. Earth Surface Processes and Landforms 21(8):701-723.

Walder JS, O’Connor JE (1997) Methods for predicting peak discharge of floods caused by failure of natural and constructed earthen dams. Water Resources Research 33(10):23372348.

Costa JE (1985) Floods from Dam Failures. Open-File Report of the U.S. Geological Survey, No. 85-560. United States Department of the Interior Geological Survey. Colorado (United States).

Macdonald TC, Langridgemonopolis J (1984) Breaching characteristics of dam failures. Journal of Hydraulic Engineering-Asce 110(5):567-586.

Westoby MJ, N Glasser F, Brasington J, Hambrey MJ, Quincey DJ, Reynolds JM (2014) Modelling outburst floods from moraine-dammed glacial lakes. Earth-Science Reviews $134: 137-159$.

Morris MW, Hassan MAAM, Vaskinn KA (2007) Breach formation: Field test and laboratory experiments. Journal of Hydraulic Research 45(sup1):9-17.

Singh KP, Snorrason A (1982) Sensitivity of outflow peaks and flood stages to the selection of 
dam breach parameters and simulation models (Dam Safety Program). SWS Contract Report, No. 288. Department of Energy and Natural Resources, State Water Survey Division, University of Illinois. Illinois (United States).

Singh KP, Snorrason A (1984) Sensitivity of outflow peaks and flood stages to the selection of dam breach parameters and simulation models. Journal of Hydrology 68(1-4):295-310.

Hagen VK (1982) Re-evaluation of design floods and dam safety. In Proc., 14th Congress of International Commission on Large Dams. Rio de Janeiro, Brazil: International Commission on Large Dams.

Froehlich DC (1995) Peak outflow from breached embankment dam. Journal of water resources Planning and Management 121(1):90-97.

O’Connor JE, Beebee RA (2009) Floods from natural rock-material dams. In Megaflooding on Earth and Mars, edited by Burr DM, Carling PA, Baker VR, 128-171. Cambridge University Press, Cambridge (United Kingdom).

Manville V (2001) Techniques for evaluating the size of potential dam-break floods from natural dams. Institute of Geological and Nuclear Sciences, New Zealand.

Haeberli W (1983) Frequency and characteristics of glacier floods in the Swiss Alps. Annals of Glaciology 4:85-90.

O’Connor JE (1993) Hydrology, hydraulics, and geomorphology of the Bonneville Flood. Special Paper 274. Geological Society of America. Colorado (United States).

Costa JE (1983) Paleohydraulic Reconstruction of Flash-Flood Peaks from Boulder Deposits in the Colorado Front Range. Geological Society of America Bulletin 94(8):986-1004.

Capart H (2013) Analytical solutions for gradual dam breaching and downstream river flooding. 
Water Resources Research 49(4):1968-1987.

Fread DL (1996) Dam-breach floods. In Hydrology of disasters, edited by Singh VP, 85-126. Springer, Heidelberg (Germany).

Morris MW, Hassan M, Kortenhaus A, Geisenhainer P, Visser PJ, Zhu Y (2009) Modelling breach initiation and growth. In Flood Risk Management: Research and Practice, edited by Samuels P, Huntington S, Allsop W, Harrop J, 581-591. AK Leiden, The Netherlands: CRC Press: Taylor \& Francis Group.

Bradley WC, Mears AI (1980) Calculations of flows needed to transport coarse fraction of Boulder Creek alluvium at Boulder, Colorado. Geological Society of America Bulletin 91(3-Part II):1057-1090.

Helley EJ (1969) Field measurement of the initiation of large bed particle motion in Blue Creek near Klamath, California. US Geological Survey Professional Paper 562-G. US Government Printing Office, Washington DC (United States).

Williams GP (1970.) Manning formula-A misnomer?. Journal of the Hydraulics Division 96:193-200.

Cui ZJ (2013) Diamicts and Environment. Hebei Science and Technology Press. Shijiazhuang, (China). (in Chinese)

Chen RC, Chen J, Ma JX, Cui ZJ (2019) Quartz grain surface microtextures of dam-break flood deposits from a landslide-dammed lake: A case study. Sedimentary Geology 383:238-247. Local Chronicle Compilation Committee of the Qiang People's Autonomous County of Maowen and the Tibetan and Qiang People's Autonomous Prefecture of Aba, Sichuan Province (1997) Hydrographic system. In Qiang People's Autonomous County Annals of 
Maowen, edited by Yang GS, 90-94. Sichuan Lexicographical Press, Chengdu (China). (in Chinese)

Korup O, Montgomery DR, Hewitt K (2010) Glacier and landslide feedbacks to topographic relief in the Himalayan syntaxes. Proceedings of the National Academy of Sciences of the United States of America 107(12):5317-5322.

Hood WC, Aslan A, Betton C (2014) Aftermath of a stream capture: Cactus Park lake spillover and the origin of East Creek, Uncompahgre Plateau, western Colorado. Geosphere 10(3):447-461.

Yunus AP, Oguchi T, Hayakawa YS (2016) Remote identification of fluvial knickzones and their imprints on landscape morphology in the passive margins of Western Arabia. Journal of Arid Environments 130:14-29.

Burchsted D, Daniels M, Wohl EE (2014) Introduction to the special issue on discontinuity of fluvial systems. Geomorphology 205:1-4.

Korup O, Tweed F (2007) Ice, moraine, and landslide dams in mountainous terrain. Quaternary Science Reviews 26(25-28):3406-3422.

Ouimet WB, Whipple KX, Royden LH, Sun Z, Chen Z (2007) The influence of large landslides on river incision in a transient landscape: Eastern margin of the Tibetan Plateau (Sichuan, China). Geological Society of America Bulletin 119(11-12):1462-1476.

Pratt-Sitaula B, Garde M, Burbank DW, Oskin M, Heimsath A, Gabet E (2007) Bedload-tosuspended load ratio and rapid bedrock incision from Himalayan landslide-dam lake record. Quaternary Research 68(1):111-120.

Korup O (2012) Earth's portfolio of extreme sediment transport events. Earth-Science Reviews 
112(3-4):115-125.

Montgomery DR, Hallet B, Liu YP, Finnegan N, Anders A, Gillespie A, Greenberg HM (2004)

Evidence for Holocene megafloods down the Tsangpo River gorge, southeastern Tibet. Quaternary Research 62(2):201-207.

Cutler PM, Colgan PM, Mickelson DM (2002) Sedimentologic evidence for outburst floods from the Lauorentide Ice Sheet margin in Wisconsin, USA: Implications for tunnel-channel formation. Quaternary International 90(1):23-40.

Carling PA (2013) Freshwater megaflood sedimentation: What can we learn about generic processes? Earth-Science Reviews 125:87-113.

Xu H, Chen J, Cui ZJ, Chen RC (2020) Sedimentary facies and depositional processes of the Diexi Ancient Dammed Lake, Upper Minjiang River, China. Sedimentary Geology, 398:105583, 15 pp.

Liu WM, Hu KH, Carling PA, Lai ZP, Cheng T, Xu YL (2018) The establishment and influence of Baimakou paleo-dam in an upstream reach of the Yangtze River, southeastern margin of the Tibetan Plateau. Geomorphology 321:167-173.

van Gorp W, Temme AJAM, Baartman JEM, Schoorl JM (2014) Landscape evolution modelling of naturally dammed rivers. Earth Surface Processes and Landforms 39(12):1587-1600.

van Gorp W, Schoorl JM, Temme AJAM, Reimann T, Wijbrans JR, Maddy D, Demir T, Veldkamp T (2016) Catchment response to lava damming: integrating field observation, geochronology and landscape evolution modelling. Earth Surface Processes and Landforms 41(11):1629-1644. 

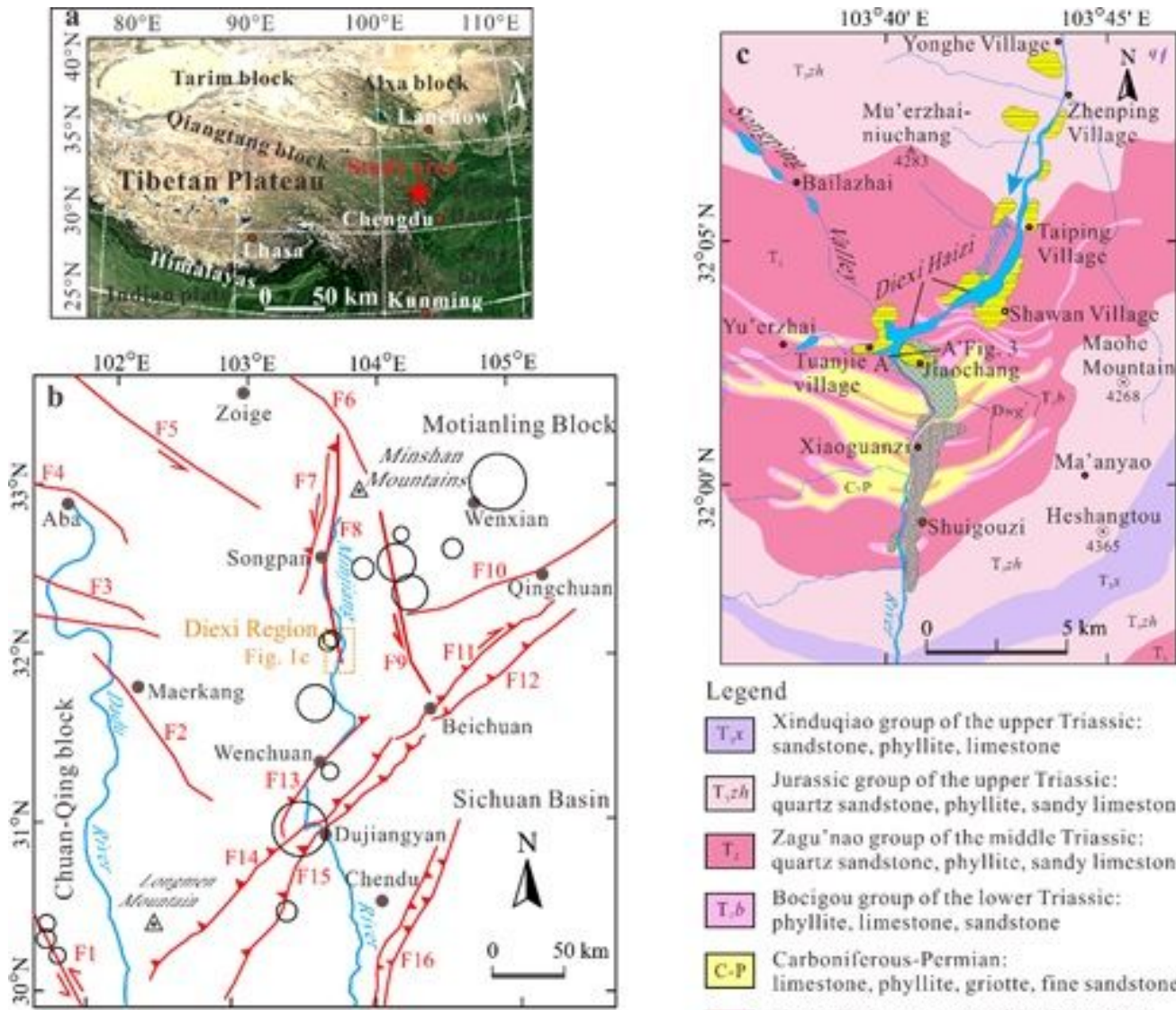

Legend
T, Xinduqiao group of the upper Triassic:
$T, x$ sandstone, phyllite, limestone
$T, A$ Jurassic group of the upper Triassic:
Tuartz sandstone, phyllite, sandy limestone

Tagu'nao group of the middle Triassic:

quartz sandstone, phyllite, sandy limestone

It B Bocigou group of the lower Triassic:

phyllite. limestone, sandstone

C.P. Carboniferous-Permian:

limestone, phyllite, griotte, fine sandstone

Legend

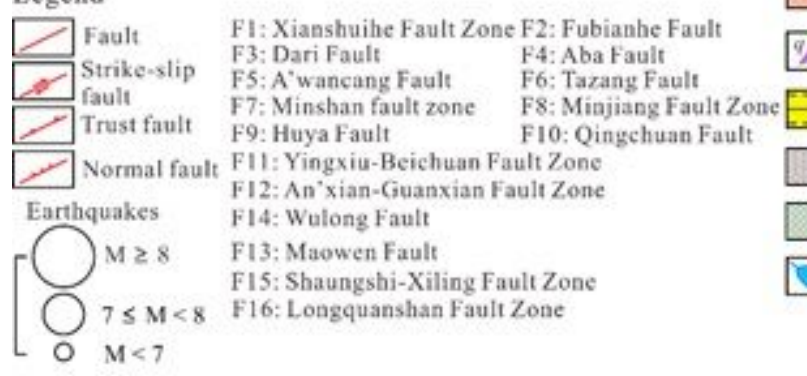

Dex Upper Weiguan group of the Devonian:

sandstone, phyllite, sandy limestone

Quartz vein

Lacustrine deposits

$\square$ Outburst deposits

$\square$ Residual ancient landslide dam

River and lake

\section{Figure 1}

Study area. a. Location map. b. Outline of the active tectonics in the East Tibetan Plateau. c. The lithologies of the exposed bedrocks in the study area, and the distribution of the DALL. The Diexi Haizi lakes are modern barrier lakes induced by the Ms. 7.5 Diexi earthquake in 1933. 

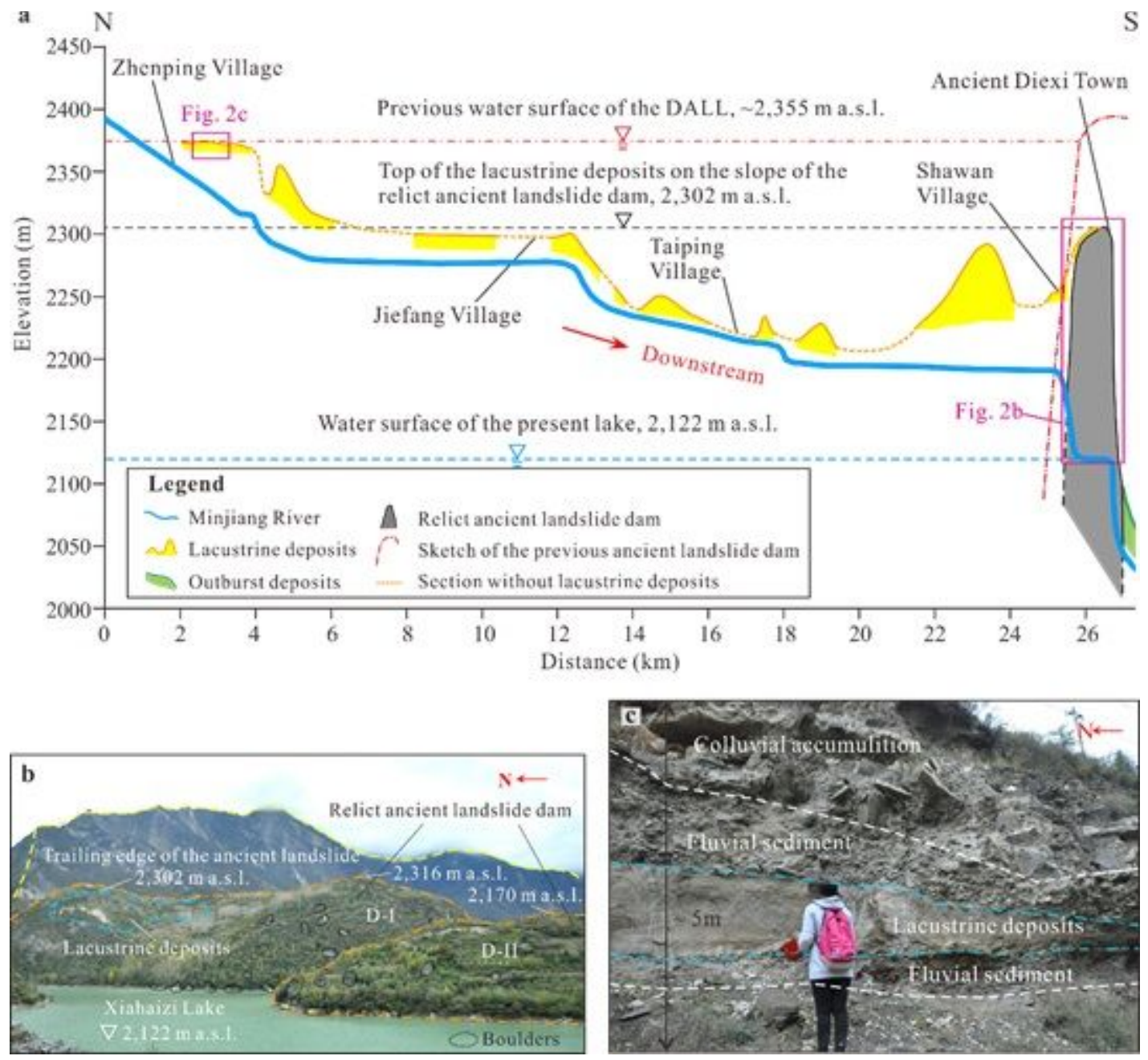

Figure 2

a. Longitudinal profile of the DALL and the relict ancient landslide dam on the left bank of Minjiang River. The line of previous ancient landslide dam is schematic. b. Geomorphological features of the relict Diexi ancient landslide dam (modified from Ma et al., 2018). Dam D-I is the main relict body of the Diexi ancient landslide dam. Dam D-II is the residue of dam body originated from the left bank slopes, which locates in the Xiahaizi Lake. c. Geomorphological and sedimentary features of the lacustrine deposits near Zhenping Village, which was inferred the end of DALL. 


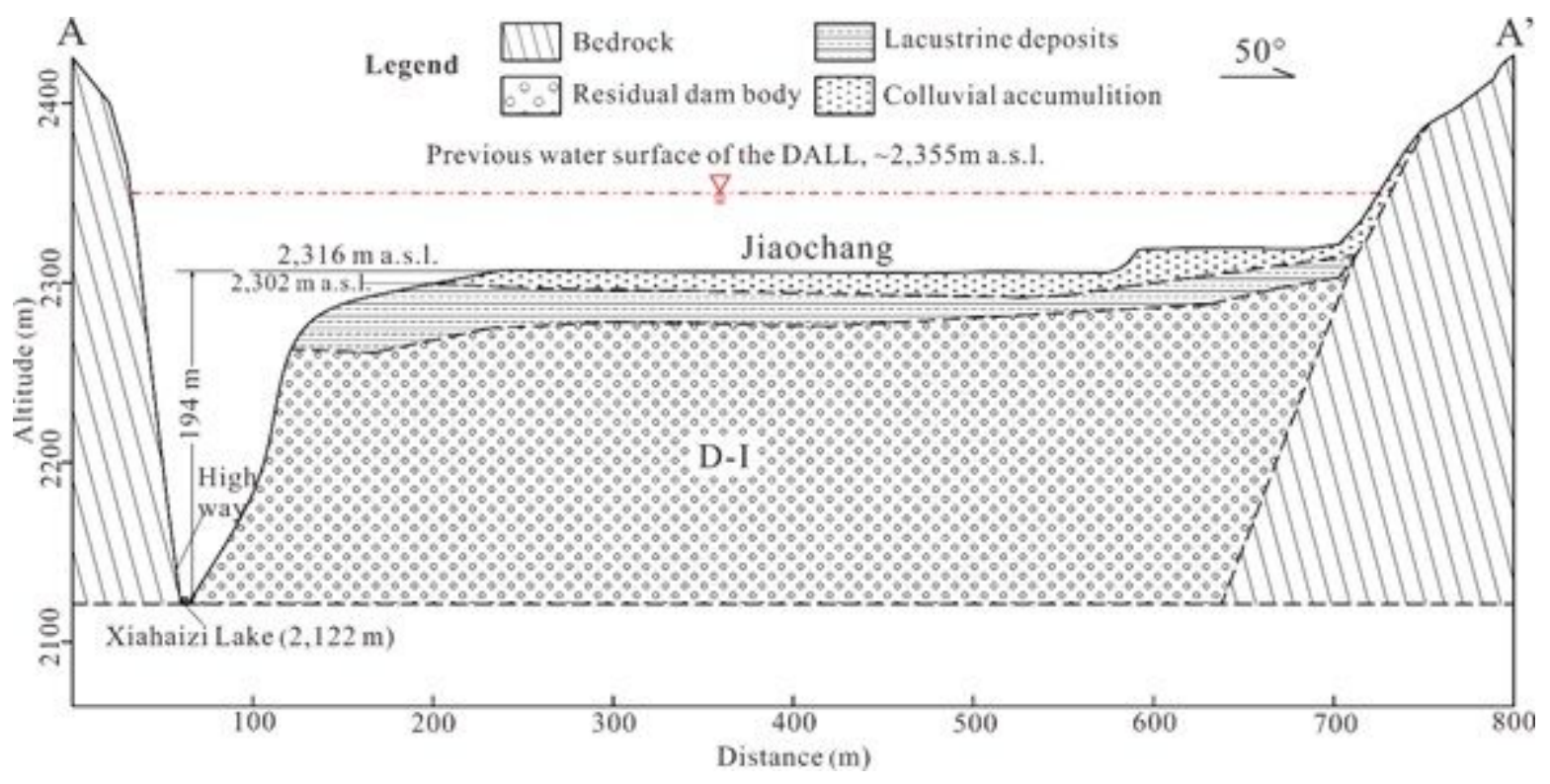

\section{Figure 3}

Sketch of the longitudinal cross-section A-A' showing the geomorphology and geology of the Diexi landslide dam and the spatial relation (see Fig. 1c for the location) (modified from Ma et al., 2018).

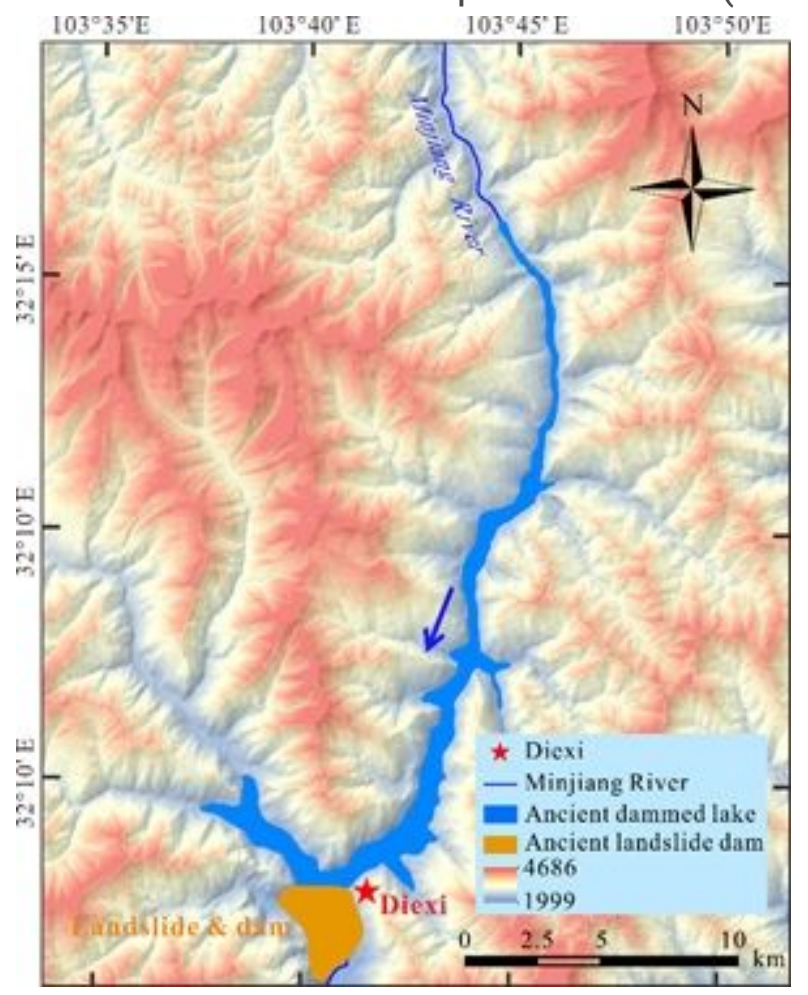

Figure 4

Map showing the reconstructed original lake surface area and responding volume of the DALL with a water surface elevation of $2,355 \mathrm{~m}$. 

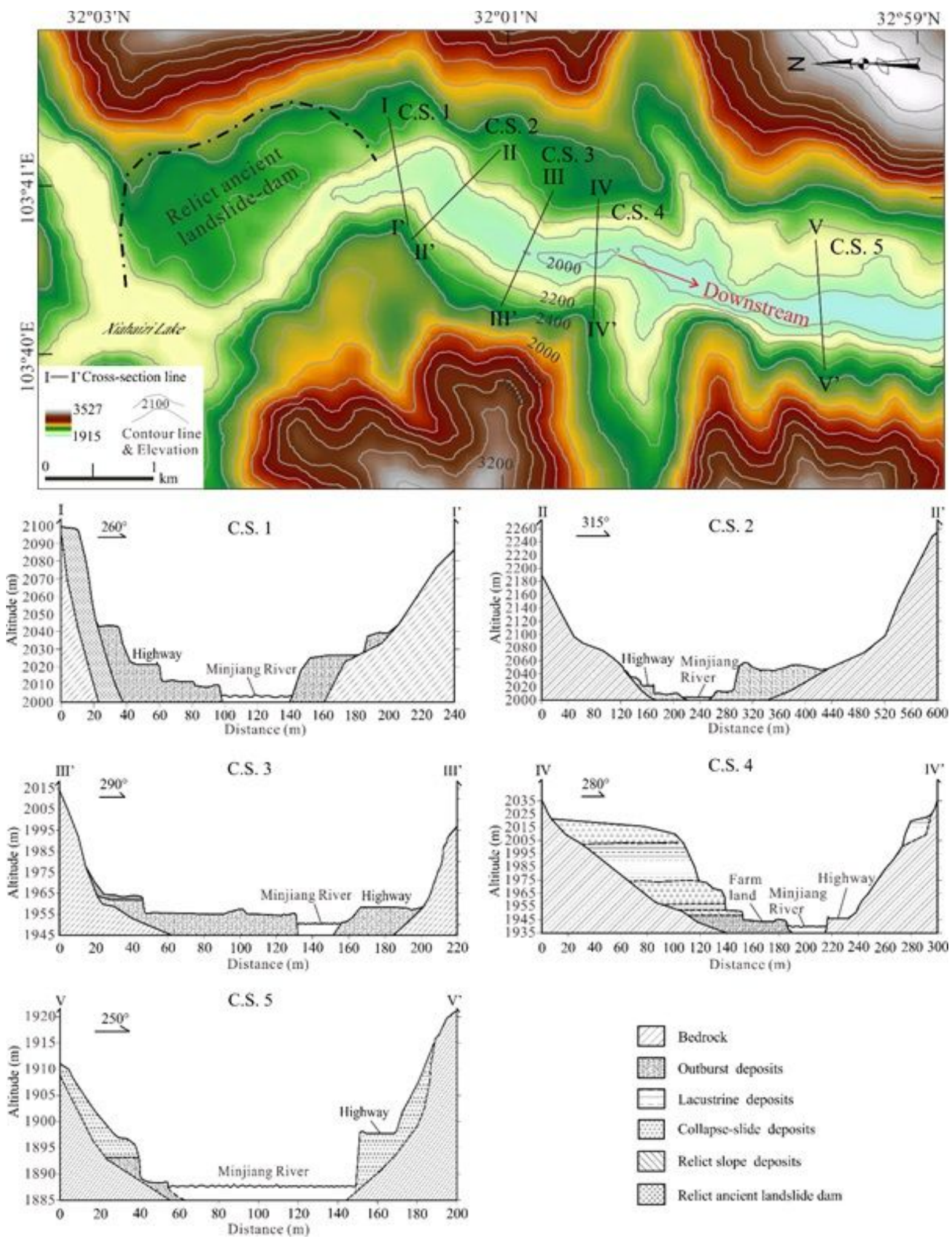

Figure 5

Locations and sketches of the cross-sections established to calculate the peek discharge of the Diexi ancient LLOFs by the boulder competence methods. 


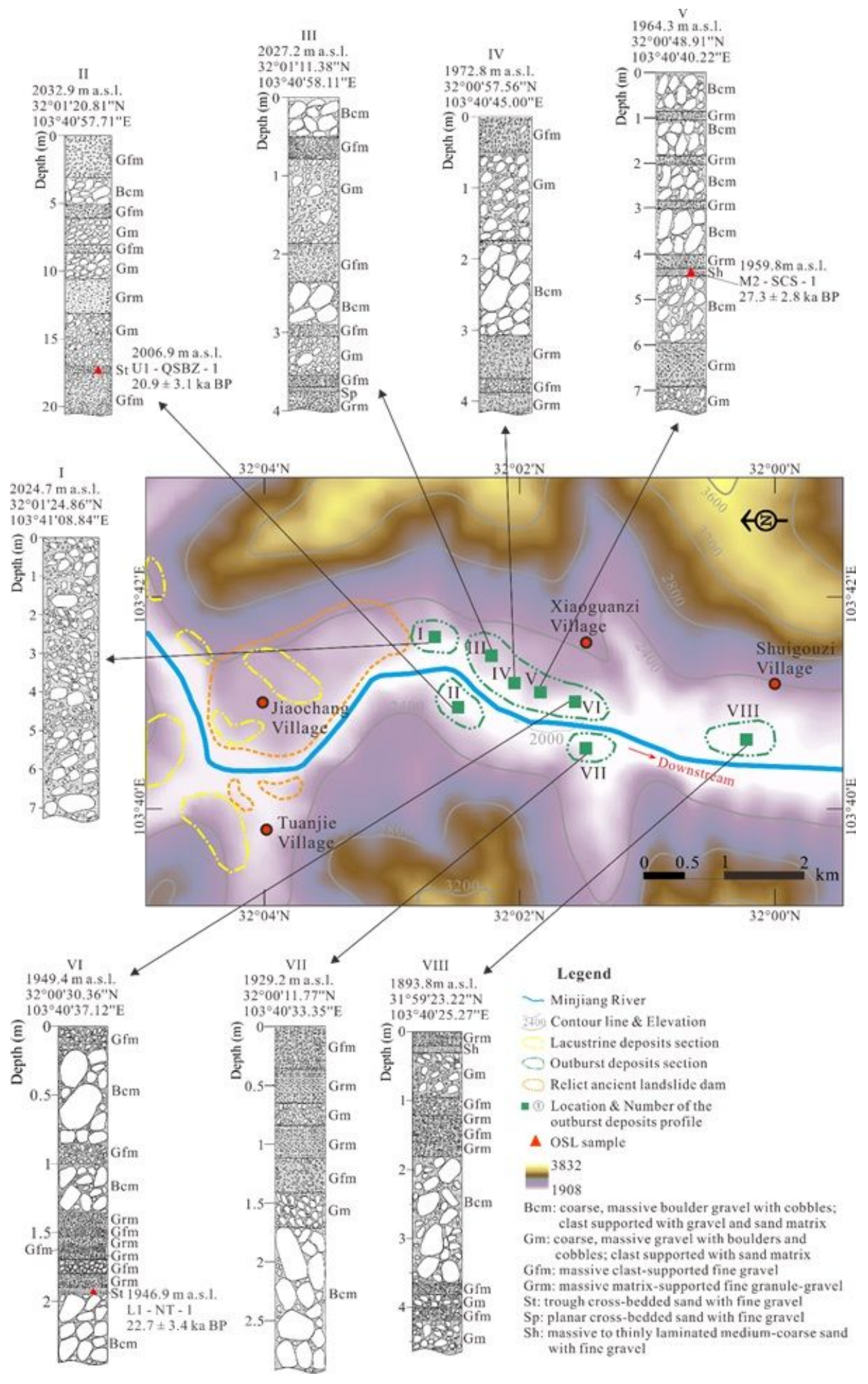

Figure 6

Distribution and lithological sketches of the outburst deposits sections in Diexi Region. The OSL dating samples and ages were from Ma et al. (2018). 

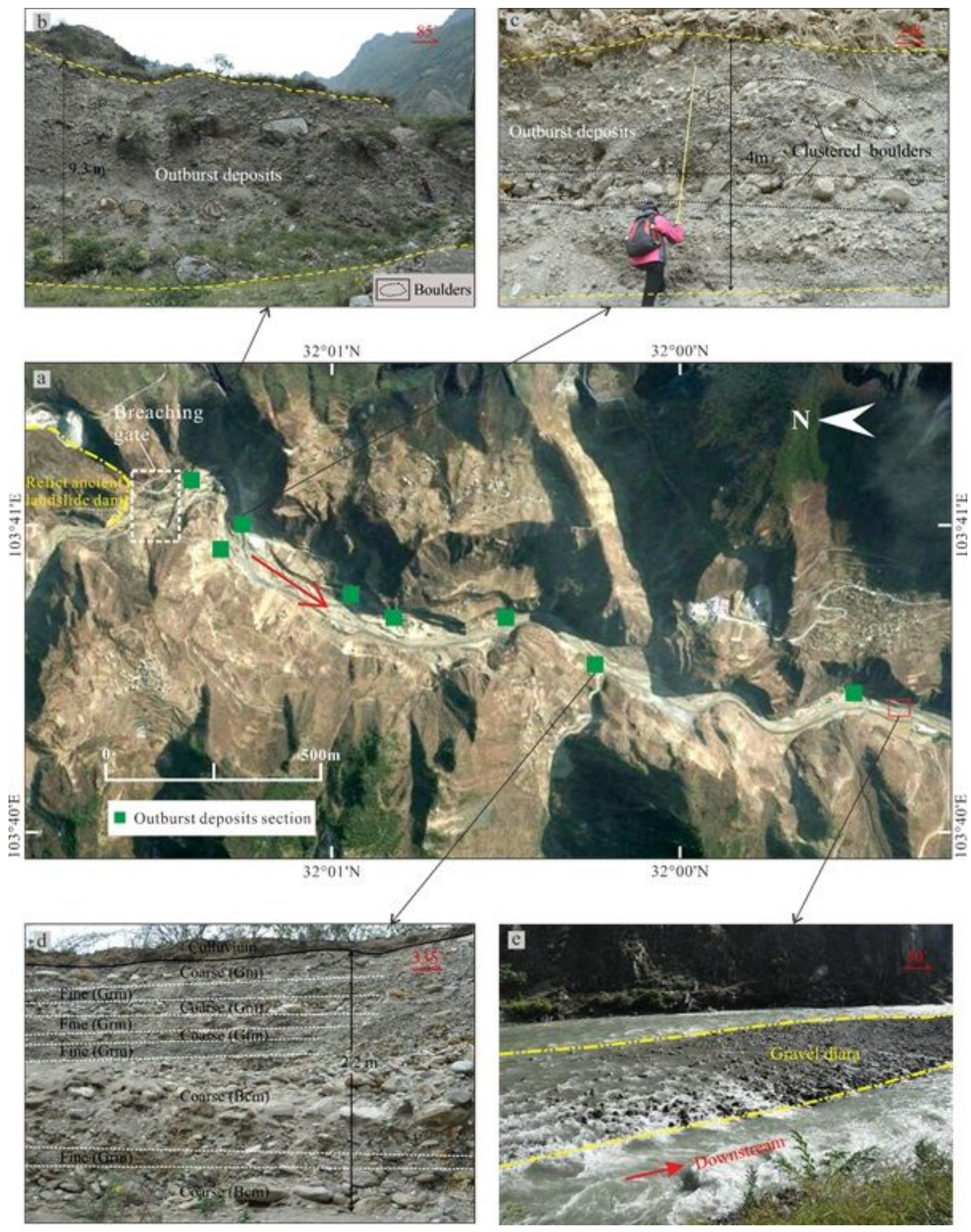

\section{Figure 7}

Field photographs showing the sedimentary characteristics of the outburst deposits profiles in Diexi area. a. Geomorphology and spatial locations the outburst deposits sections. The base image was captured and modified from 'Google Earth' with a date of January 9th, 2016. b. Sedimentary features of the outburst deposits profile near the breaching gate. c. Sedimentary features of the outburst deposits profile in the downstream of sit b with a distance of about $0.3 \mathrm{~km}$. d. Rhythmite interbedded units composed of 
coarser gravel layers and finer sand and gravel layers in the profile, about $5 \mathrm{~km}$ away from the landslide dam in the lower reach of outburst deposits (modified from Ma et al., 2018). e. Gravel diara located in the middle of Minjiang River formed by well-rounded and well-sorted pebble gravels near the end of outburst deposits near the end of outburst deposits.

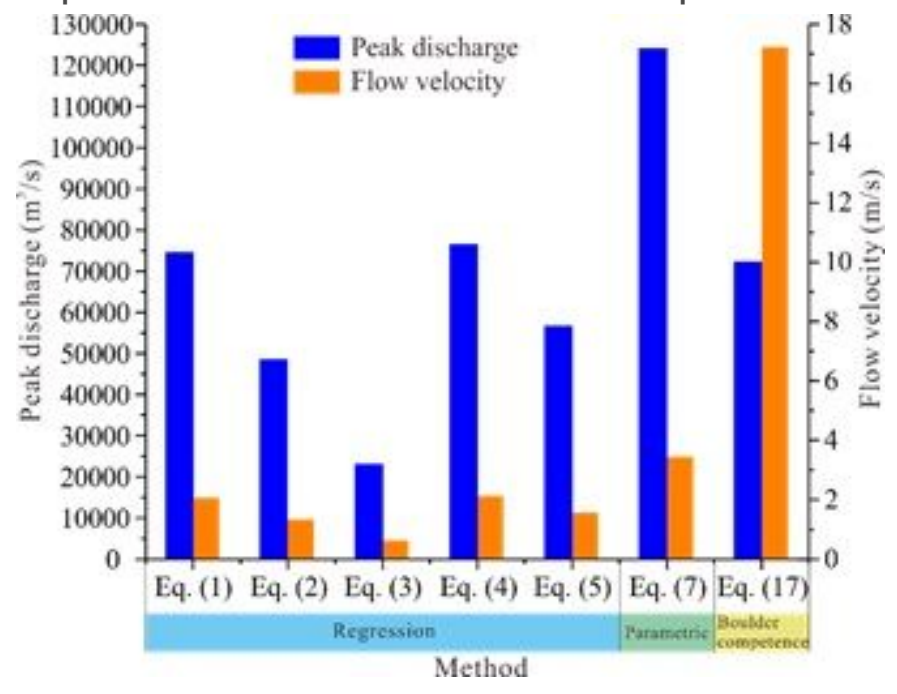

\section{Figure 8}

Histogram of the estimated maximum peak discharges and flow velocities by the methods of regression, parametric and boulder competence.

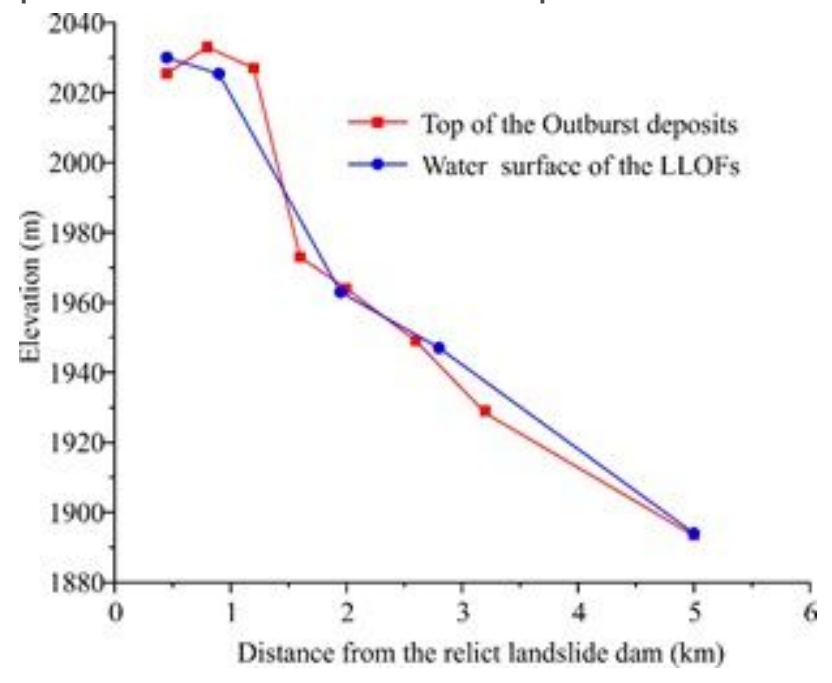

\section{Figure 9}

Top elevation of the outburst deposits and water surface elevation of the LLOFs reconstructed by the boulder competence methods.

\section{Figure 10}

River slope and channel width of the Minjiang River in Diexi Region. 


\section{Supplementary Files}

This is a list of supplementary files associated with this preprint. Click to download.

- Tables.pdf 